\title{
DUKUNGAN SOSIAL BAGI PEREMPUAN PRA-SEJAHTERA MELALUI PROGRAM KEUANGAN MIKRO: STUDI KASUS PADA KOPERASI MITRA DHUAFA CABANG CIKALONGKULON
}

\author{
William Cahyawan ${ }^{1}$ \& Sari Viciawati Machdum ${ }^{2}$ \\ Fakultas Psikologi, Universitas Indonesia, Depok 16424, Indonesia \\ Korespondensi: \\ 'e-mail: williamcahyawan@gmail.com; ${ }^{2}$ e-mail: sari.viciawati@ui.ac.id
}

\begin{abstract}
Microfinance is one of the popular strategies to eradicate poverty and achieve gender equality. In practice, microfinance must not only focus on economic aspects, but also on the social ones. For this reason, the researcher seeks to examine the forms of support carried out by microfinance in an attempt to achieve its mission. The main theory of this research is social support theory from Lord and Hutchison (1993), consists of practical, mentoring, and moral support. This research use qualitative method with the type of case study. Study was conducted on Koperasi Mitra Dhuafa Cabang Cikalongkulon. Six participants participated in this research. Research explained that the practical support provided training to members and also provided in the form of diverse savings and loan services. Meanwhile, the mentoring support is analysis capability members to repayment and monitoring the use of them. Finally, the moral support is in the form of visiting activities for members with problems and not problems. Moral support is one of the important elements that distinguish Komida from others.
\end{abstract}

Article history:

Received 11 March 2019

Received in revised form 25 April 2019

Accepted 29 May 2019

Available online 22 July 2019

\section{Keywords:} microfinance; pre-prosperous women; social support

\begin{abstract}
Abstrak - Keuangan mikro adalah salah satu strategi populer dalam upaya pengentasan kemiskinan dan mencapai kesetaraan gender. Dalam praktiknya, keuangan mikro tidak boleh hanya berfokus pada aspek ekonomi, namun juga aspek sosial. Untuk itu, peneliti berupaya mengkaji bentuk-bentuk dukungan yang sebaiknya dilakukan oleh keuangan mikro dalam upaya mencapai misinya. Teori utama dalam penelitian ini adalah teori dukungan sosial dari Lord dan Hutchison (1993), meliputi dukungan praktikal, mentoring, dan moral. Penelitian ini menggunakan metode kualitatif studi kasus. Studi dilakukan pada Koperasi Mitra Dhuafa Cabang Cikalongkulon. Partisipan dalam penelitian berjumlah enam orang. Hasil riset menunjukkan bahwa dukungan praktikal dalam bentuk pelatihan dan tersedianya layanan simpanan, serta pinjaman yang beragam. Sementara itu, dukungan mentoring berupa analisis kemampuan pengembalian pinjaman, serta monitoring terhadap kegunaan pinjaman. Terakhir, dukungan moral berupa kegiatan kunjungan kepada anggota bermasalah dan tidak bermasalah. Dukungan moral menjadi salah satu elemen penting yang membedakan dari Lembaga Keuangan Mikro yang lainnya.
\end{abstract}

Kata Kunci: dukungan sosial; keuangan mikro; perempuan pra-sejahtera 


\section{PENDAHULUAN}

Kesetaraan gender merupakan tujuan dan faktor penting untuk mencapai pembangunan berkelanjutan. Tujuan ini ditekankan pada salah satu pedoman prinsip dari Agenda Pembangunan Perserikatan Bangsa-Bangsa tahun 2030 (United Nations Development Program, 2019), terutama pada penekanan konsep 'leaving no one behind'. Kesetaraan gender menekankan pada kesetaraan status dan nilai pada laki-laki dan perempuan. Penilaian terhadap manusia sudah seharusnya tidak dipandang sebagai superior atau inferior hanya karena berdasarkan status gender (Alba, 2018).

Salah satu strategi yang dilakukan untuk mencapai kesetaraan gender adalah melalui program keuangan mikro dengan tujuan utama memberdayakan perempuan dan mengentaskan kemiskinan. Keuangan mikro mengacu pada upaya pengaturan, baik secara formal dan informal, untuk menawarkan layanan finansial kepada masyarakat miskin (Brau \& Woller, 2004). Layanan ini mulai dikenal secara luas sejak Muhammad Yunus menciptakan Grameen Bank. Praktik keuangan mikro dilakukan dengan memberikan kredit mikro tanpa adanya jaminan tradisional dan jumlah pinjaman relatif kecil (Yunus, 2007).

Menurut Pomeranz (2004), lebih dari 80 persen industri keuangan mikro memang ditargetkan kepada perempuan. Partisipasi perempuan dalam program keuangan mikro merupakan salah satu langkah untuk menolak norma dan budaya gender yang telah terjadi selama ini sehinga membuat perempuan sulit berkembang dan tidak mampu membuat pilihannya sendiri (Swain \& Wallentin, 2009). Keuangan mikro diharapkan membuat masyarakat miskin mampu memiliki akses memperoleh sejumlah uang sehingga dapat mengambil kesempatan yang ada. Kondisi ini mendorong peningkatan kualitas hidup masyarakat (Warby, 2014).

Walaupun keuangan mikro diyakini mampu menjadi program strategis dalam upaya mencapai kesetaraan gender dan mengentaskan kemiskinan, namun perdebatan terhadap kehadiran dan peran LKM (Lembaga Keuangan Mikro) masih cukup banyak dibahas. Polemik yang terjadi disebabkan oleh keharusan LKM untuk mencapai kemandirian finansial (non-subsidi) dan melakukan komersialisasi. Keharusan LKM mencapai kemandirian membuat LKM terpaksa harus memperoleh profit dan mencapai pertumbuhan dengan cara membebankan suku bunga yang cukup tinggi kepada anggota (Milgram, 2001).

Pandangan positif beranggapan bahwa upaya mencapai kemandirian menunjang keberlanjutan dari LKM karena LKM mampu menghasilkan keuntungan. Dalam praktiknya, keuangan mikro berupaya mengikuti prinsip bank yang baik dan tetap berperan dalam upaya 
pengentasan kemiskinan (Morduch, 2000). Sebaliknya, pandangan yang pesimis menyatakan bahwa performa dari LKM yang dilakukan dengan berorientasi pada profit akan menghasilkan kondisi yang tidak memuaskan. Ife (2013) menyatakan bahwa LKM dengan pendekatan ini malah bisa menjadi sumber yang menyebabkan masalah baru bagi para anggotanya.

Beberapa penelitian yang ditemukan juga cukup banyak memberikan kritik terhadap komersialisasi LKM. Milgram (2001) berpendapat bahwa apabila LKM terlalu berfokus pada kemandirian, maka dapat membuat LKM gagal menunaikan misi utamanya untuk menjadikan masyarakat miskin sebagai target sasaran dan memfasilitasi terciptanya pengusaha kecil. Penelitian terdahulu telah menunjukkan bagaimana perempuan penerima layanan keuangan mikro malah mengalami peningkatan hutang. Banyak perempuan memilih kabur dari rumah atau desanya karena gagal melakukan pembayaran kembali atau akibat dari bangkrutnya bisnis yang mereka jalani (Banerjee \& Jackson, 2017). Adanya bunga tinggi juga membuat perempuan takut dan mengurangi keberanian perempuan untuk mengakses pinjaman untuk kepentingan bisnisnya (Teye, Coleman, \& Oykere, 2016).

Dampak dari masalah ini tidak hanya dirasakan oleh anggota, namun juga LKM itu sendiri. Banyak anggota mengalami gagal bayar sehingga LKM kemudian dirugikan karena harus mengalami kebangkrutan dan menghentikan pembiayaan Usaha Mikro, Kecil, Menengah (UMKM) (Syahrizal \& Machdum, 2016). Salah satu kasus keuangan mikro menghebohkan terjadi di India, tepatnya di negara bagian Andhra Pradesh. Business Insider (2012) menjelaskan bahwa praktik LKM di Andhra Pradesh mengakibatkan lebih dari dua ratus masyarakat miskin kemudian terlilit hutang dan memilih bunuh diri. Negara menyalahkan peran LKM karena memicu terjadinya hutang yang sangat tinggi.

Contoh-contoh kasus di atas memberikan pandangan lain tentang bahaya dan kekhawatiran besar pada praktik keuangan mikro. Meskipun demikian, Ife (2013) berpendapat bahwa masalah yang dialami oleh LKM jangan sampai membuat kita menghilangkan peran keuangan mikro selama ini. Kita lebih baik memfokuskan diri pada bagaimana layanan yang seharusnya dilakukan, sehingga program benar-benar dapat berjalan dengan optimal. Hal ini menjadi penting karena praktik keuangan mikro semakin bertumbuh dan banyak bermunculan. Otoritas Jasa Keuangan (OJK) mencatat hingga bulan Januari 2018, jumlah pelaku LKM mencapai 186 entitas dan telah mengalami peningkatan pesat dari sebelumnya (Mahadi \& Kartika, 2018).

Walaupun terjadi beragam masalah, perlu disadari bahwa tidak semua praktik LKM mengalami kegagalan dan kejatuhan. Salah satu LKM yang justru terus bertumbuh dan berkembang 
adalah Koperasi Mitra Dhuafa (Komida). Dalam praktiknya, Komida mengadopsi konsep Grameen Bank dan memiliki target sasaran eksklusif untuk perempuan miskin (Mekar, 2017). Komida juga menerapkan praktik pinjaman berbasiskan kelompok (group based lending). Selain itu, layanan finansial yang menjadi produk Komida pun sudah sangat berkembang, meliputi berbagai jenis layanan pinjaman dan simpanan. Layanan pinjaman tidak hanya sebatas pada pinjaman untuk usaha, melainkan juga pinjaman untuk harta (seperti pemasangan listrik), pendidikan, sanitasi, dan renovasi rumah (Komida, 2018).

Komida telah berkembang secara pesat beberapa tahun belakangan hingga memiliki anggota yang jumlahnya mencapai sekitar 509 ribu dan terdapat 230 kantor cabang Komida dengan 12 kantor regional yang tersebar di berbagai wilayah di Indonesia (per 31 Juli 2018) (W. Trimulyani, personal communication, September, 2018). Selain itu, sesuai hasil laporan tahunan Komida tahun 2017, Komida juga memiliki tingkat pengembalian pinjaman (repayment rates) yang sangat tinggi, yaitu mencapai 99.33 persen atau dapat juga dikatakan bahwa Portfolio at Risk (PAR) masih terjaga di angka .66 persen (KSP Mitra Duhafa, 2018).

Berdasarkan fenomena di atas, kita tidak boleh mengesampingkan peran dari keuangan mikro sebagai strategi mencapai kesetaraan gender dan mengentaskan kemiskinan. Hanya saja, penting bagi LKM untuk mempelajari dan mengeksplorasi bagaimana layanan yang sebaiknya diberikan, sehingga program dapat berjalan dengan optimal dan tidak membebankan perempuan sebagai anggota. Untuk itu, peneliti tertarik untuk meneliti bagaimana dukungan sosial yang dilakukan oleh Komida kepada perempuan pra-sejahtera. Lord dan Hutchison (1993) menjelaskan pentingnya dukungan sosial dalam memberikan dampak bagi pemberdayaan pada masyarakat yang tidak berdaya. Menurut mereka, individu yang merespons secara lebih menyenangkan terhadap krisis atau transisi hidup adalah mereka yang percaya pada diri mereka sendiri dan kapabilitas yang dimiliki (self-efficacy), serta menerima dukungan dari orang lain untuk mengembangkan kesadaran dan tindakan mereka.

Penelitian ini diharapkan dapat menjelaskan berbagai bentuk dukungan yang dilakukan Komida, sehingga dapat menjadi contoh bagi LKM yang lain agar tidak hanya berkembang dari sisi bisnis, tetapi juga mampu menunaikan misi originalnya untuk mencapai kesetaraan gender dan pengentasan kemiskinan. 


\section{Dukungan Sosial}

Dukungan sosial diartikan sebagai seperangkat hubungan yang saling terkoneksi di antara kelompok orang yang menyediakan pola pengasuhan (dalam berbagai bentuk) dan menyediakan tambahan kekuatan sebagai upaya untuk melanjutkan hidup hari demi hari (Whittaker \& Garbarino, 1983). Dukungan sosial juga dijelaskan sebagai bentuk komunikasi verbal atau non-verbal antara penerima manfaat dan penyedia layanan dalam upaya mengurangi ketidakpastian terkait situasi, diri sendiri, orang lain, atau hubungan yang terjalin, dan berfungsi untuk meningkatkan persepsi atas kontrol personal pada pengalaman seseorang (Albrecht \& Adelman, 1987).

Tipe dukungan sosial mengacu pada kategorisasi spesifik mengenai perilaku suportif yang memiliki kategori luas, seperti dukungan berwujud atau instrumental dan dukungan emosional atau peningkatan harga diri (Malecki \& Demaray, 2002). Sementara itu, House (1981) membagi dukungan sosial ke dalam empat tipe. Pertama, dukungan emosional yang terkait dengan upaya berbagi pengalaman hidup, meliputi empati, cinta, rasa percaya, dan kepedulian. Kedua, dukungan instrumental yang meliputi bantuan yang bersifat nyata dan layanan yang secara langsung membantu orang yang membutuhkan. Ketiga, dukungan informasional yang terdiri dari saran dan informasi yang dapat diberikan kepada individu. Keempat, dukungan penilaian, yaitu informasi yang berguna terkait tujuan untuk melakukan evaluasi diri, terutama umpan balik konstruktif, afirmasi, dan perbandingan sosial.

Teori dukungan sosial lain yang dijelaskan oleh Lord dan Hutchison (1993) dianggap oleh peneliti lebih sesuai dengan konteks penelitian karena mengaitkan peran dukungan sosial dan pemberdayaan perempuan. Menurut Lord dan Hutchison (1993), umumnya seseorang merasa tidak berdaya disebabkan oleh beberapa faktor. Pertama, terkait dengan isolasi sosial, pada kelompok perempuan berpendapatan rendah umumnya mengalami kondisi masa kecil atau masa dewasa yang sulit dan mereka seringkali menyatakan bahwa dirinya kekurangan dukungan dalam hidup mereka. Kedua, kegagalan layanan dan sistem yang membuat individu-individu ini tetap berada pada kondisi ketergantungan yang berkepanjangan dan transisi menuju pemberdayaan menjadi sangat terhambat. Ketiga, kemiskinan merupakan pengalaman yang membuat mereka lemah dan ini dialami oleh hampir seluruh perempuan dengan pendapatan rendah dan beberapa individu dengan disabilitas. Keempat, kekerasan atau penyiksaan merupakan kontributor lain dari ketidakberdayaan, khususnya pada kelompok perempuan dengan pendapatan rendah. Konsekuensi dari kebergantungan yang panjang pada individu membentuk self-esteem (harga diri) yang rendah, pilihan yang sedikit, dan keterbatasan pengalaman untuk mengambil keputusan. 
Lord dan Hutchison (1993) menjelaskan transisi menuju pemberdayaan sosial bersifat unik dan merupakan proses yang berkelanjutan. Dukungan dari orang lain menjadi faktor penting dalam mengembangkan kesadaran dan tindakan hingga akhirnya mampu meningkatkan efikasi diri individu dan membuat mereka berdaya. Bandura (1994) mendefinisikan efikasi diri sebagai keyakinan individu terhadap kapabilitas mereka untuk menghasilkan tingkat kinerja yang memengaruhi aktivitas-aktivitas yang berdampak pada kehidupan mereka. Keyakinan terhadap efikasi diri menentukan bagaimana individu merasa, berpikir, mampu memotivasi diri sendiri, dan berperilaku.

Menurut Lord \& Hutchison (1993), terdapat tiga bentuk dukungan yang dapat dilakukan untuk membentuk efikasi diri individu. Pertama, dukungan praktikal, yaitu dukungan nyata dengan menolong orang yang sedang mengalami perjuangan untuk menjadi lebih berdaya. Kedua, dukungan melalui mentoring. Kebanyakan perempuan dengan pendapatan rendah membutuhkan individu dalam hidupnya untuk menjadi mentor atau model. Ketiga, dukungan moral, yaitu kemampuan untuk mendengarkan. Terkadang, dukungan moral datang dari sesama kelompok, keluarga atau teman, dan pekerja layanan. Dukungan moral membuat individu memiliki kesempatan untuk memastikan institusi tempat mereka bernaung, meningkatkan kepercayaan terhadap diri, dan menyadari kapasitas.

\section{METODE}

\section{Partisipan}

Partisipan berjumlah enam orang yang terdiri dari tiga staf lembaga dan tiga anggota. Cabang Cikalongkulon dipilih karena merupakan cabang terbaik Komida secara nasional pada tahun 2007. Kantor cabang Cikalongkulon per akhir Desember 2018 memiliki lebih dari 5,450 anggota dengan tingkat kemacetan kredit yang sangat baik, yaitu terjaga di angka .50 persen. Kecamatan Cikalongkulon merupakan salah satu bagian dari Kabupaten Cianjur, tepatnya wilayah Cianjur bagian tengah yang penduduknya memiliki mata pencaharian di bidang pertanian (Nurwati \& Mulyana, 2017).

Partisipan dari staf lembaga yang dipilih adalah satu manajer dan dua staf lapangan. Kebanyakan staf bekerja di sebuah kantor cabang selama 1-2 tahun karena selalu ada sistem mutasi untuk menghindari kecurangan. Staf di Komida umumnya berusia antara 18-25 tahun. Partisipan 
dari anggota adalah dua ketua centre dan satu anggota reguler. Ketua centre adalah ketua dari satu tempat kegiatan transaksi antara anggota dan staf. Anggota yang dipilih minimal telah bergabung dengan Komida selama 2 tahun. Suami para anggota yang menjadi partisipan seluruhnya turut bekerja untuk membantu perekonomian keluarga. Seluruh partisipan sudah memiliki anak dan terdapat beberapa anggota yang anaknya sudah bekerja, yaitu anak anggota A dan C. Berikut adalah tabel data informan.

Tabel 1.

Rangkuman Data Demografi Subjek Staf Komida Cabang Cikalongkulon

\begin{tabular}{llll}
\hline Keterangan & Subjek 1 & Subjek 2 & Subjek 3 \\
\hline Nama (inisial) & Staf A & Staf B & Staf C \\
Usia & 26 tahun & 22 tahun & 25 tahun \\
Daerah Asal & Cianjur & Cianjur & Sukabumi \\
Jenis Kelamin & Laki-Laki & Laki-Laki & Laki-Laki \\
Status & Menikah & Belum menikah & Belum menikah \\
Lama Bekerja & 2 tahun & 2 tahun & 1 tahun \\
(di Cikalongkulon) & & & \\
\hline
\end{tabular}

Tabel 2.

Rangkuman Data Demografi Subjek Anggota Komida Cabang Cikalongkulon

\begin{tabular}{llll}
\hline Keterangan & Subjek 4 & Subjek 5 & Subjek 6 \\
\hline Nama (inisial) & Anggota A & Anggota B & Anggota C \\
Usia & 42 tahun & 30 tahun & 51 tahun \\
Tempat tinggal & Desa Lembahsari & Desa Neglasari & Desa Warudoyong \\
Jumlah anak & 4 & 3 & 2 \\
Usaha anggota & Usaha jahit & Usaha warung & Usaha kredit \\
Kerja suami & Usaha tani & Kerja bangunan & Penjaga Resort \\
Lama keanggotaan & 10 tahun & 11 tahun & 11 tahun \\
Status & Anggota & Ketua & Ketua \\
\hline
\end{tabular}

\section{Desain}

Penelitian ini menggunakan pendekatan penelitian kualitatif dengan metode pengambilan data berupa wawancara dan observasi. Dalam melakukan wawancara, peneliti memilih menggunakan teknik semi-terstruktur. Tipe penelitian yang digunakan adalah studi kasus. Creswell (2013) menjelaskan pendekatan kualitatif dengan studi kasus merupakan upaya untuk memperoleh pemahaman mendalam (in-depth) melalui analisis data dari berbagai sumber. Studi kasus berupaya menjelaskan semua detail terkait kasus, di mana tema atau isu diidentifikasi oleh peneliti. Penggunaan berbagai sumber data menghasilkan triangulasi yang berkontribusi pada validitas 
penelitian yang diinvestigasi (Creswell, 2013). Pada penelitian ini, peneliti melakukan studi pada kasus pilihan yang bertujuan untuk memahami isu spesifik, yaitu tentang dukungan sosial yang diberikan oleh LKM. Studi dilakukan di Komida cabang Cikalongkulon sebagai representasi terbaik dari praktik Komida.

\section{Prosedur}

Persiapan awal dilakukan dengan meminta izin secara formal kepada kantor Komida Pusat yang terletak di Jakarta. Proses perizinan dilakukan supaya peneliti dapat memperoleh akses ke kantor cabang Komida yang telah ditentukan untuk melakukan penelitian. Setelah Komida Pusat memberikan izin, peneliti berangkat menuju Kecamatan Cikalongkulon, Kabupaten Cianjur sebanyak dua kali, yaitu pada bulan Desember 2018 dan Januari 2019. Dalam mencari partisipan, peneliti ikut terlibat bersama dengan para staf untuk melakukan kegiatan. Selama staf melakukan kegiatan di lapangan, peneliti meminta izin untuk melakukan wawancara kepada anggota. Staf yang menemani peneliti ketika turun lapangan dijadikan partisipan untuk staf Komida cabang Cikalongkulon.

\section{Teknik Analisis}

Teknik analisis data yang digunakan dalam penelitian ini adalah analisis coding. Neuman (2013) mendefinisikan coding sebagai upaya mengatur data mentah menjadi kategori konseptual dan membuat tema atau konsep. Coding pada penelitian kualitatif dilakukan dalam tiga tahap. Pertama adalah open coding, yaitu memeriksa data yang telah ditemukan dan meringkasnya menjadi kategori atau kode analisis awal. Kedua adalah axial coding, yaitu peneliti menyusun kode, menautkannya, dan menemukan kategori analisis utama. Ketiga adalah selective coding, yaitu melibatkan semua data dan kode sebelumnya, secara selektif mengidentifikasi dan memilah data yang akan mendukung kategori konseptual yang telah dikembangkan. Sesuai penjelasan sebelumnya, peneliti menggunakan kerangka konseptual dari teori dukungan sosial.

\section{ANALISIS DAN HASIL}

Peneliti melakukan analisis hasil penelitian menggunakan teori dari Lord dan Hutchison (1993) yang membagi teori dukungan sosial ke dalam tiga bentuk, yaitu dukungan praktikal, dukungan mentoring, dan dukungan moral. Berikut adalah hasil analisisnya: 


\section{Dukungan Praktikal bagi Anggota}

\section{Pelatihan kepada Anggota Baru}

Komida sebagai salah satu LKM yang berupaya mencapai kemandirian dan komersialisasi memiliki tujuan untuk memperoleh profit dan mengalami pertumbuhan. Salah satu indikator utama yang diamati adalah pertumbuhan jumlah anggota. Untuk itu, Komida memiliki beberapa strategi untuk merekrut dan mencari anggota baru. Terdapat dua strategi umum yang dilakukan oleh Komida. Pertama adalah ekspansi ke wilayah baru, sedangkan strategi kedua adalah menambahkan anggota baru di wilayah yang sudah terbentuk kelompok-kelompoknya (tambal sulam anggota). Hal ini seperti yang diutarakan oleh staf A.

"Kalau anggota baru itu, ada dua cara. Pertama, dengan cara pembentukan centre baru gitu kan. Atau dengan cara, centre yang sudah ada, kita kembangkan. Jadi misalnya, baru ada 15 anggota, kita kembangkan jadi 20 anggota atau 17. Kalau misalnya memungkinkan centre bisa kita kembangkan, lebih baik ke centre. Kita dateng lagi ke centre, cari anggota yang mau ikutan..satu dua gitu, langsung kita data. Kalau misalnya bikin centre baru, kita harus cari wilayah baru, lebih susah." (Staf A, 12 Desember 2018)

Strategi pertama yang dilakukan oleh Komida adalah ekspansi ke wilayah baru. Di awal, Komida akan melakukan sosialisasi kepada aparatur desa dan masyarakat di satu wilayah baru. Komida memperkenalkan diri danprogram pinjaman yang akan diberikan, serta menanyakan kesediaan para perempuan untuk bergabung menjadi anggota Komida. Jika para calon anggota menyetujui dan memiliki niatan untuk bergabung, maka mereka harus membentuk kelompok yang terdiri dari 4-5 anggota di dalamnya. Satu wilayah pertemuan (centre) baru minimal terdiri dari 10 anggota yang dipecah ke dalam 2 kelompok. Setelah sebuah centre baru terbentuk, staf B menjelaskan bahwa calon anggota diharuskan untuk mengikuti kegiatan pelatihan selama 5 hari. Pelatihan ini berisi berbagai informasi mengenai Komida, baik penjelasan tentang syarat-syarat anggota dalam melakukan peminjaman, layanan simpan pinjam yang dimiliki oleh Komida, dan keharusan setiap anggota untuk melakukan tanggung jawab bersama atau tanggung renteng. Kegiatan pelatihan ini disebut dengan Latihan Wajib Kelompok (LWK).

"Masuk LWK..anggota bilangnya sekolah itu, latihan wajib kelompok. Itu ada 5 hari, hari terakhir itu ujian anggota. Di hari pertama itu pengenalan lembaga lebih detailnya lagi, misalkan pembiayaan ada berapa, suku margin ada berapa 
persen per produk. Dari hari ke hari beda, dengan cara penyampaian pun tergantung kita supaya bisa dimengerti. Ngga harus pakai bahasa Indonesia, malah kebanyakan pakai bahasa Sunda biar bisa dimengerti." (Staf B, 14 Januari 2019)

Pada tahap terakhir, para calon anggota akan diberikan tes untuk mengetahui sejauh mana pemahaman mereka terkait informasi yang telah diberikan. Kegiatan tes ini disebut dengan uji pengesahan dan menjadi syarat untuk dapat melakukan pencairan pinjaman. Setiap calon anggota harus hadir penuh selama 5 hari kegiatan. Apabila terdapat anggota yang berhalangan, maka ia gagal untuk memperoleh pinjaman.

Selain membentuk centre baru, calon anggota juga dapat bergabung di kelompok yang wilayah pertemuannya telah berjalan. Jumlah anggota dalam kelompok dapat bertambah dari 4-5 orang hingga mencapai 8 orang. Proses pelatihan kepada anggota baru di centre yang telah berjalan berbeda dengan pelatihan di sebuah centre baru. Proses pelatihan diadakan bersamaan ketika staf melakukan kegiatan transaksi simpan pinjam tiap minggu kepada seluruh anggota dalam centre. Calon anggota diwajibkan mengikuti pertemuan selama 4 minggu berturut-turut. Setelahnya, mereka baru dapat menjadi anggota, melakukan pengajuan, serta pencairan pinjaman.

"Hooh, cuma kalau mereka yang cuma gabung 1 anggota, dia ngga masuk LWK. Tapi dia harus mengikuti kumpulan atau centre, apabila anggota baru..belum pernah bergabung gitu ya, dia harus ikut sebanyak 4 kali. Baru pertama kali gitu pinjam ke Komida. Kalau misalkan sudah pernah ikut, tapi keluar..pengen masuk lagi, itu 2 minggu juga cukup.” (Staf A, 12 Desember 2018)

Bagi anggota lama yang keluar, namun ingin masuk kembali, proses belajar lebih singkat, yaitu hanya berlangsung selama 2 minggu saja karena anggota lama sudah memiliki pengetahuan tentang Komida sebelumnya dan hanya perlu diingatkan kembali.

Dengan adanya pelatihan dan proses pembentukan kelompok, hal ini mendorong anggota untuk berpartisipasi aktif dalam program. Anggota lama juga memiliki kesempatan untuk menyuarakan pendapatnya, apakah bersedia apabila terdapat anggota baru yang ingin bergabung. Anggota umumnya hanya memilih anggota baru yang sudah mereka kenal dan tahu asal usulnya karena anggota harus bersedia untuk melakukan tanggung renteng apabila anggota lain tidak dapat mengembalikan pinjaman. Apabila para anggota di dalam centre setuju, maka calon anggota tersebut dapat dipertimbangkan untuk bergabung dengan Komida. 
"Deket-deket, ibu mah engga ambil yang jauh, kalau ada apa-apa bisa deket nyusulnya. Jadi ada ibu yang dateng, bu pengen ikutan. Baru ibu tanya ke ibu-ibu yang lain, ibu ini mau ikutan, setuju engga. Kalau setuju, yah ayo masuk. Tapi kalau engga setuju mah, ya engga..entar ibu yang harus nanggung kan. ” (Anggota C, 16 Januari 2019)

\section{Pemberian Fasilitas Layanan Pinjaman}

Sebagai penyedia praktik layanan keuangan mikro, Komida memiliki layanan utama berupa layanan simpan pinjam. Komida memberikan pinjaman dengan syarat yang relatif mudah, yaitu anggota hanya diharuskan menyerahkan fotokopi Kartu Tanda Penduduk (KTP) dan Kartu Keluarga (KK), serta tanda tangan suami sebagai penjamin. Hal ini sesuai dengan apa yang disampaikan oleh anggota B. Di samping itu, seluruh anggota di dalam kelompok juga memiliki tanggung jawab bersama apabila terdapat anggota yang mengalami gagal bayar (tanggung renteng).

"Gampang, terus ngga pakai persyaratan aneh-aneh, suami saya paling ngga suka tuh kalau minjem uang harus aneh-aneh. Misalnya kayak minta foto suami istri. Kalau sekarang memang sih harus KTP ama KK ya..” (Anggota B, 15 Januari 2019)

Walaupun syarat peminjam adalah perempuan, namun Komida tidak melarang apabila suami anggota yang menggunakan pinjaman tersebut. Yang terpenting, anggota ataupun suami benar menggunakan pinjaman untuk usaha.

"Usaha suaminya boleh, kalau pinjaman umum itu..anggota yang belum punya usaha, tapi niat untuk usaha..bisa itu untuk umum. Kalau mikrobisnis harus ada usahanya." (Staf A, 12 Desember 2018)

Syarat lainnya yang harus disanggupi oleh anggota adalah kehadiran tiap minggu di centre. Fungsi kehadiran adalah melakukan kegiatan transaksi, yaitu anggota harus membayar angsuran kepada Komida. Berdasarkan hasil observasi, kegiatan transaksi umumnya berlangsung selama kurang lebih 30 menit. Dalam satu hari, staf dapat mengunjungi 4-7 centre yang letaknya saling berdekatan. Kegiatan dimulai dengan doa dari ketua centre, dilanjutkan dengan ucapan salam pembuka dari staf, mengisi absensi, dan penagihan angsuran. Selain itu, staf juga bertanya apakah anggota ingin menabung atau tidak pada minggu tersebut. 
Dalam melakukan kegiatan transaksi, para staf juga meminta bantuan dari ketua centre untuk terlibat aktif dalam memimpin kumpulannya. Mereka memiliki tugas untuk memastikan siapa saja anggota yang hadir dan tidak hadir dalam kegiatan transaksi, melakukan penagihan angsuran, dan menanyakan jumlah simpanan yang ingin ditabung oleh anggota. Anggota B bercerita bahwa dirinya sejak pagi sudah mengumpulkan uang angsuran dan simpanan kepada setiap anggotanya, sekaligus mengingatkan bahwa pada hari tersebut ada kegiatan transaksi. Hal ini dilakukan supaya ketika kegiatan sudah dimulai, semua anggota sudah hadir tepat waktu dan uang sudah terkumpul dengan tepat. Diharapkan, kegiatan transaksi tidak molor waktunya karena dapat menghambat kegiatan transaksi di centre lain.

"Alhamdullilah suka nganterin ke rumah. Saya yang nagih kalau yang susah. Tapi kebanyakan nganterin semua. Saya mah kalau udah pada setor, langsung taro ke bukunya, si B segini juga langsung ditaro. Saya tahu nabungnya berapa, setornya berapa..aku tahu, pinjemnya berapa juta, aku tahu.” (Anggota B, 15 Januari 2019)

Saat ini, bentuk dan jenis pinjaman Komida semakin beragam. Produk pinjaman yang diberikan tidak terbatas pada pinjaman untuk usaha (umum dan mikrobisnis), namun juga pinjaman harta (misalnya listrik), pendidikan, sanitasi, dan renovasi rumah. Penagihan angsuran dilakukan oleh staf setiap seminggu sekali ketika ada pertemuan di centre. Produk pertama yang boleh dimanfaatkan oleh anggota adalah produk pinjaman umum dengan maksimal plafon pinjaman sebesar tiga juta rupiah. Setelahnya, anggota baru diperbolehkan untuk melakukan pinjaman dengan jumlah lebih besar atau memanfaatkan produk pinjaman yang berbeda.

Untuk itu, Komida perlu melakukan upaya-upaya untuk mencegah anggota bermasalah. Salah satunya dengan memberikan syarat yang lebih sulit kepada anggota yang mau melakukan peminjaman non-umum atau harta, yaitu telah bergabung minimal selama 2 tahun. Hal ini dikarenakan jumlah pinjaman non-umum atau harta biasanya lebih besar. Syarat lain untuk memperoleh pinjaman non-umum atau harta juga lebih sulit. Misalnya, anggota yang ingin melakukan pinjaman untuk mikrobisnis (sebesar 10-15 juta), anggota diwajibkan memiliki simpanan yang ditabungkan di Komida sebesar minimal 20 persen dari jumlah pinjaman dan memiliki Surat Pemberitahuan Pajak Terhutang (SPPT) sebagai bukti apabila anggota benar mempunyai usaha legal.

Dengan adanya layanan pinjaman, para anggota dapat memulai atau mengembangkan usahanya. Anggota A dan C menggunakan pinjaman untuk modal pengembangan usaha. Anggota A 
menggunakan modal yang diberikan untuk membeli mesin jahit dan bahan-bahan. Sementara itu, anggota $\mathrm{C}$ menggunakan pinjaman untuk modal membeli barang di Tanah Abang dan dijual kembali secara kredit kepada para tetangganya.

"Sekarang saya pake yang juki. Alhamdullilah, semenjak saya pinjem ke sini, saya udah beli mesin Juki.cuma obrasan punya. Tapi yah sekarang fasilitas jahit udah ada di rumah, jadi udah ngga mesti keluar. Kekurangan paling kayak kancing, baru keluar beli." (Anggota A, 15 Januari 2019)

"Itu buat jual beli barang, kreditan. Misalkan buat kreditan..beli barang, lebaran. Apalagi kan sekarang udah anak pada mau sekolah, misalnya buat pakaian, apa aja gitu yang dia perluin." (Anggota C, 16 Januari 2019)

Walaupun demikian, anggota A juga menggunakan sebagian pinjaman untuk pemenuhan kebutuhan sehari-hari, seperti kebutuhan rumah tangga dan biaya sekolah.

"Kalau saya mah jadi separo ke jahit, separo-paro buat bantu ke rumah..buat bantu sekolah. Saya pinjemnya mah umum, ngga pinjem untuk pendidikan. Buat pendidikan, saya dipisah. Ambilnya dari umum aja, daripada beberapa cabang. Menging satu, tapi gede gitu sekalian.” (Anggota A, 15 Januari 2019)

Sementara itu, anggota B menggunakan pinjaman untuk membuka usaha warung. Sebelum menjadi anggota, ia belum memiliki usaha apapun.

"Saya buka warung, itu warung saya yang disitu. Di warung kayak gini, jualan bakso kadang, jualan bakmi. Dulu jualan seblak kan, tapi bosen..jadi mau ganti. Ada juga jual rokok, sembako, gitu-gitu." (Anggota B, 15 Januari 2019)

Bahkan saat ini, anggota B juga telah mengikuti layanan pinjaman renovasi rumah. Ia mengakui dengan adanya pinjaman renovasi rumah, membuat rumah menjadi lebih nyaman dan ia juga dapat memperbesar usaha warungnya.

"Kalau sekarang dari pinjaman 2 juta, sekarang udah 6 juta. Sekarang sudah ambil renovasi 10 juta." (Anggota B, 15 Januari 2019) 
"Iya jadi bagus, ruang tamu kan asalnya kecil..asalnya tempat duduk, sekarang jadi rumah. Tempat duduk beda lagi, buat lagi, sekarang rumahnya agak besar. Sekarang kamar asalnya dua, jadi tiga." (Anggota B, 15 Januari 2019)

Anggota pun mengakui bahwa sejauh ini mereka umumnya tidak memiliki masalah dalam pengembalian pinjaman. Anggota memiliki beberapa cara dalam upaya melakukan pengembalian pinjaman secara rutin. Misalnya, anggota B telah memiliki posisi tawar yang lebih tinggi di keluarga. Ia dan suami memiliki pembagian tugas terkait dengan pengeluaran bulanan. Pendapatan dari hasil usaha anggota B digunakan untuk kebutuhan sehari-hari dan uang jajan anak, sementara pendapatan suami digunakan untuk membayar angsuran.

"Kalau angsuran Komida mah itu khusus, apalagi renovasi, itu khusus suami saya yang nanggung. Kan kita bagi tugas, dia angsuran ke Komida, aku buat jajan anak-anak, gitu. Jadi dibagi tugas." (Anggota B, 15 Januari 2019)

Sementara itu anggota $\mathrm{A}$ dan $\mathrm{C}$ biasanya mampu membayar angsuran dengan menggunakan uang sendiri. Bahkan, sebagian pendapatan anggota A pun dapat digunakan untuk pemenuhan kebutuhan sehari-hari keluarga dan anak. Walaupun, anggota $\mathrm{C}$ juga bercerita ada kalanya ia harus menggunakan uang pemberian dari suami, terutama jika orang yang meminjam kepada dirinya masih menunggak atau belum jatuh tempo.

"Saya juga biasanya mampu lah pakai uang sendiri, hasil jait cukup. Lebihnya bisa pakai buat uang jajan anak atau bantu buat sekolah, kebutuhan. Yah namanya orang desa, buat itu-itu aja sih.” (Anggota A, 15 Januari 2019)

"Ya dari uang ibu (setoran), ya dari mana aja sih setoran mah, yang penting bisa setor lah. Bapak kan juga ada itu jaga villa. Engga gede tapi pak, paling 2 juta, 2 juta setengah. Ya alhamdullilah, dari penghasilan juga." (Anggota C, 16 Januari 2019)

\section{Pemberian Fasilitas Layanan Simpanan}

Komida juga menyediakan fasilitas simpanan bagi anggota. Layanan simpanan yang dimiliki oleh Komida pun beragam. Simpanan pokok, wajib, dan pensiun adalah simpanan yang harus diikuti oleh anggota. Simpanan pokok adalah biaya awal ketika perempuan berniat menjadi anggota. Simpanan wajib dan pensiun diserahkan ketika awal pencairan sebesar 5 persen dan akan 
dikembalikan setelah anggota keluar. Simpanan wajib juga diserahkan tiap minggu sebesar .1 persen dari total pinjaman.

Sementara itu, Komida juga memiliki simpanan sukarela atau hari raya. Kehadiran layanan simpanan turut membantu anggota menabung untuk berjaga-jaga atau rencana masa depan. Kedua simpanan ini sifatnya tidak wajib. Anggota boleh menabung di simpanan sukarela ataupun mengambil simpanan kapanpun ia butuhkan. Sementara, simpanan hari raya sifatnya lebih kaku karena anggota harus berkomitmen melakukan simpanan sesuai jumlah yang disepakati hingga setahun dan dikembalikan menjelang lebaran.

Menurut staf $\mathrm{C}$, layanan simpanan membantu anggota untuk berjaga-jaga dan memiliki cadangan untuk mengangsur ketika sedang tidak memiliki uang karena kondisi usaha yang dijalankan oleh anggota memang tidak selalu berada dalam kondisi baik. Ada kalanya usaha anggota sepi atau mengalami penurunan. Oleh karena itu, salah satu fungsi layanan simpanan adalah untuk meminimalisir risiko tersebut.

"Kalau simpenan wajib, memang wajib. Kalau simpanan sukarela atau hari raya, kita saranin. Kenapa harus nabung? Itu buat jaga-jaga sih, karena namanya usaha tidak tentu, kadang di bawah kadang di atas. Takutnya kalau lagi kosong, bisa ngambil dari simpanan sukarela. Makanya itu sangat disaranin, meskipun hanya beberapa ribu, tapi kan membantu." (Staf C, 16 Januari 2019)

Anggota A juga menjelaskan apabila layanan simpanan sangat membantu mereka untuk menabung karena selama ini masalah jarak menjadi sebuah kesulitan untuk menabung di bank. Anggota A menyatakan bahwa banyak anggota yang memiliki jumlah simpanan sukarela mencapai satu hingga dua juta rupiah. Beberapa anggota lain menabung lebih besar dari jumlah angsurannya tiap minggu dari hasil dari usahanya atau titipan anak.

"Alhamdullilah kalau di sini, kelompok ini. Malahan di sini mah, gini angsuran sedikit, tabungan besar. Saya mah tabungan bisa sampai sejuta, itu nabung kecilkecil 10 ribu seminggu. Kadang diambil kalau ada kekurangan. Yang lain ada yang nabung udah sampe 2 juta yah. Alhamdullilah, itu kadang uang buat bayarin angsuran gitu." (Anggota A, 15 Januari 2019)

Anggota B juga bercerita bahwa dirinya mampu membeli kulkas hasil dari simpanan hari raya. Anggota B rutin menabung tiga puluh ribu setiap minggunya. Walaupun, ia perlu menambahkan sekitar satu juta rupiah karena uang simpanannya masih kurang. Dengan adanya 
kulkas tersebut, anggota B mampu berjualan secara lebih efisien karena barang-barang sisa tidak terbuang. Ia juga dapat menjual es dan cukup laku dibeli oleh anak-anak.

"Kemarin hari raya buat beli kulkas kan (tabungan). Itu kemarin ikut yang 30 ribu, nombok satu juta kemarin. Tapi, aku kan ambil yang umum, jadi bisa dari situ. Itu kulkas buat bikin es, terus juga buat sayuran kan. Itu kalau engga ada kulkas kan, suka kebuang. Jadi kayak tempe atau tahu kan, engga cepet basi, jadi bisa dua sampai tiga hari. Terus minuman biasanya juga engga ada buat anak-anak, yang dikemas gitu, sekarang ada." (Anggota B, 16 Januari 2019)

Bahkan, anggota B juga sudah berencana untuk mengambil uang simpanan wajibnya apabila sang anak sudah masuk ke SMK karena biaya sekolah yang dibutuhkan besar. Apabila ia mengambil simpanan wajib, maka ia harus keluar dari keanggotaan Komida. Namun, anggota B boleh masuk kembali dan melakukan peminjaman dengan jumlah plafon minimal, yaitu tiga juta rupiah. Uang pinjaman ini yang sebagian direncanakan untuk usaha dan sebagian lainnya untuk menambah biaya sekolah anaknya.

"Sekarang kan pinjemnya gede, SMK juga ongkosnya gede, lebih dari SMP. Jadi kan nanti dua tahun lagi, sampe dua jutaan wajibnya..aku mau ambil. Terus ambil lagi tiga juta, kan angsurannya kecil, cuma tujuh puluh delapan, setahun. Jadi itungannya cukup lah, ada lah buat uang pangkal itu sekarang tiga juta delapan ratus, emang sih bisa diangsur, tapi kan masih ada pakaian, terus juga tas ama sepatu." (Anggota B, 16 Januari 2019)

\section{Dukungan Mentoring bagi Anggota}

\section{Kegiatan Pendataan dan Peninjauan}

Setiap anggota yang telah atau akan melakukan pencairan pinjaman juga akan didata terlebih dahulu melalui formulir Catatan Prestasi. Kegiatan pendataan merupakan cara Komida untuk memastikan dan menganalisis kemampuan pembayaran anggota di masa yang akan datang.

"Pas mau pengajuan aja, punya anak berapa misal. Terus suaminya kerja apa, punya penghasilan buat apa aja, terus warung itu gimana. Gitu-gitu aja sih.” (Anggota B, 15 Januari 2019)

Kegiatan pendataan dilakukan untuk menentukan apakah anggota berhak untuk memperoleh pinjaman selanjutnya atau tidak, serta berapa jumlah maksimal plafon pinjaman yang dapat 
diberikan. Walaupun kegiatan pendataan adalah aspek vital, namun Komida tetap menerapkan prinsip rasa percaya kepada anggota. Hal ini yang membuat staf hanya bertanya secara lisan, sehingga tidak harus sampai melihat secara detail dan terkesan tidak percaya dengan apa yang disampaikan oleh anggota.

"Ya itu dicek aja, kita tanya aja. Ibu pendapatannya gimana? Harian atau minggu, atau bulanan? Karena kan kalau petani, atau warung beda. Dia kerja di orang lain juga beda. Pak saya memang harian gitu..sehari berapa. Karena kita grameen, yang kita garap itu perkampungan. Kalau perkotaan, kita ngga masuk..ngga boleh. Kalau grameen kan bank desa. Jadi harus natural juga, kita tanya ke anggota..ngga liat buktinya. Kalau itu yah yang ibunya ngomongin aja." (Staf A, 12 Desember 2018)

Staf juga memiliki tugas untuk melakukan peninjauan terkait kegunaan pinjaman yang telah dilakukan oleh anggota. Kondisi ini untuk memastikan bahwa anggota tidak menyalahgunakan pinjaman dan benar-benar digunakan untuk kegiatan usaha. Umumnya, staf akan segera melakukan peninjauan tidak lama setelah anggota memperoleh pencairan pinjaman.

"Kalau monitoring lebih ke pengecekan, pengecekan usaha ibu masih berjalan atau tidak. Monitoring dilakukan pas si ibu sudah cair. Kan diajukan untuk modal usaha apa, kita cek bener ngga dipakai untuk usaha itu." (Staf C, 16 Januari 2019)

Peran staf lainnya adalah melakukan kunjungan kepada anggota-anggota sebagai upaya memberikan motivasi, terutama kepada anggota yang memiliki keluhan-keluhan. Staf pun berperan untuk memberikan semangat dan tetap peduli apabila anggota mengalami hambatan dari usahanya. Staf C menjelaskan apabila ia juga berupaya membantu anggota dengan memberikan saran dan masukan terkait usaha. Walaupun pada akhirnya, keberhasilan usaha tergantung dari anggota itu sendiri.

"Tujuan lebih ke arah motivasi. Ibu kan biasanya punya keluhan gitu, kita kasih masukan gimana usaha si ibu bisa berjalan dengan normal, berjalan dengan ilmunya. Karena kan ibu biasanya hanya pakai akal, tidak dengan ilmunya." (Staf C, 16 Januari 2019)

"Yang penting pas usaha ibu lagi drop, kita jangan engga kasih motivasi. Kalau misalkan usaha lagi drop, kita kasih motivasi, anggepan si ibu ke kita, baik..oh si 
bapak benar-benar peduli. Walaupun ada kayak gini, keadaan kayak gini, mau nyempetin gitu." (Staf C, 16 Januari 2019)

\section{Dukungan Moral bagi Anggota}

\section{Dukungan bagi Anggota Tidak Bermasalah}

Staf memiliki kewajiban untuk melakukan kunjungan, baik kepada anggota yang bermasalah ataupun tidak bermasalah. Tujuan kunjungan biasanya sebagai bentuk silaturahmi dan memperkuat relasi.

"Yah kalau kunjungan itu juga penting, sebagai bentuk silaturahmi." (Staf C, 16 Januari 2019)

Kunjungan juga dilakukan kepada anggota yang sakit atau melahirkan, di mana staf juga harus memberikan bingkisan atau tanda kasih.

"Asumsi kunjungan itu ngga cuma yang bermasalah sama pinjaman. Tapi juga anggota yang sakit, juga anggota yang bagus juga kudu dikunjungin." (Staf A, 12 Desember 2018)

Ketika peneliti ikut serta dalam kegiatan transaksi, peneliti juga berkesempatan melihat staf mengunjungi anggota yang terbaring sakit, sehingga tidak dapat ikut hadir dalam kegiatan transaksi. Mereka terlibat dalam obrolan selama kurang lebih 15 menit. Kegiatan-kegiatan ini merupakan salah satu pengungkapan bentuk kepedulian staf terhadap anggota.

Anggota $\mathrm{A}$ dan $\mathrm{C}$ mengaku senang dengan pelayanan yang diberikan oleh para staf. Anggota A merasa bahwa staf Komida memberikan pelayanan yang baik dan dapat mengerti kondisi dari anggota. Anggota C juga menilai bahwa pelayanan yang diberikan Komida memberikan pengalaman menyenangkan dan membuat dirinya ingin terus bertahan di Komida. Kondisi ini yang menyebabkan anggota loyal dan banyak yang telah bergabung sangat lama hingga mencapai 10 tahun, bahkan lebih.

"Staf lapang Komida sih alhamdullilah, semenjak saya masuk sampai sekarang, alhamdullilah baik semua. Semua yang dateng kesini, ngerti misalkan, kalau misalkan ada satu orang, dua orang ngga hadir, ngerti alhamdullilah. Baik-baik semua." (Anggota A, 15 Januari 2019) 
"Ya makanya ibu mah, sampai tua, sampai ibu masih bisa duduk mah..insyallah Komida mah ngga bakalan ini. Alhamdullilah, udah seneng gitu." (Anggota C, 16 Januari 2019)

Bahkan, staf $\mathrm{C}$ juga menjelaskan apabila ada anggota yang masih berhubungan baik dengan dirinya, padahal sudah tidak ia dampingi. Staf dan anggota masih saling menanyakan kabar dan menjaga hubungan baik.

\begin{abstract}
"Seneng kalau seperti itu, bangga lah. Alhamdullilah juga si ibu ngga ngelupain saya, selalu nanya kabar saya, selalu nanyain saya. Paling telat seminggu sekali ngabarin. Padahal udah ngga di cabang saya, udah dituker. Saya dipindah, tapi alhamdullilah masih tetap. Dulu malahan ketika saya mau pindah, si ibu sampai nangis-nangis. Karena kapan lagi juga bisa ketemu, mungkin beberapa tahun. Terakhir ketemu kapan ya, di pertengahan tahun kemarin, sampai sekarang sudah ngga ketemu lagi. Tapi kontakan masih.” (Staf C, 16 Januari 2019)
\end{abstract}

\title{
Dukungan bagi Anggota Bermasalah
}

Sesuai penjabaran pada bagian sebelumnya, Komida melakukan praktik tanggung renteng untuk mengatasi risiko pinjaman bermasalah. Namun, terkadang anggota bermasalah masih memiliki angsuran berjumlah besar. Kondisi ini membuat sebagian anggota merasa terbebani apabila harus ikut bertanggungjawab secara penuh. Untuk itu, Komida tetap mengupayakan penagihan personal kepada anggota bermasalah. Meskipun penagihan tetap dilakukan kepada anggota bermasalah, Komida berpegang teguh pada prinsip tanpa kekerasan dan pelecehan.

"Ngga boleh kekerasan, ngga boleh ngambil barang. Itu semua ngga boleh. Kita pun kalau nagih, yaudah diem aja. Bu, gimana sudah ada? Ya Pak, Alhamdullilah cuma ada segini, ngga apa-apa? Iya ngga apa-apa..gitu paling. Kalau pakai kekerasan, ngga ada bedanya sama bank keliling. Misal ngga mampu bayar, Tvnya diambil, ngga boleh itu." (Staf A, 12 Desember 2018)

Dengan kekerasan, staf C berpendapat Komida tidak ada bedanya dengan bank keliling. Hal ini justru membuat anggota malah lebih sulit untuk memiliki keinginan mengembalikan pinjaman. Anggota lain pun akan segan dan malas untuk bergabung di Komida.

"Paling ke depannya ngga dikasih pinjaman lagi. Tapi kita jangan marahin juga (anggota bermasalah), takutnya apa.takutnya kita marahin, si ibu 
malah..ehhh..apa ya, pundung ya, ngga angsur juga kan, repot juga..kasian ibu-ibu yang lain." (Staf C, 16 Januari 2019)

Para staf juga berupaya memberikan dispensasi khusus kepada anggota yang tidak dapat mengembalikan pinjaman karena terjadi musibah tertentu. Bukan berarti pinjaman dihapuskan, namun Komida melakukan penangguhan pembayaran pinjaman. Kondisi ini pernah diberlakukan oleh staf B ketika ada anggotanya yang mengalami musibah kebakaran.

“Ataupun anggota terkena musibah, bisa. Misalkan anggota kebakaran. Masa sih kalau terkena musibah, kita tagih..ngga etis. Tapi harus tetap dibayar, karena kalau kebakaran kan ngga ada asuransi dari kantor. Asuransi cuma untuk kalau meninggal. Ada juga anggota saya yang kebakaran, jadi ditunda dulu sampe sekarang. Rencana itu Februari baru bayar.” (Staf B, 14 Januari 2019)

\section{DISKUSI}

Sesuai dengan penjelasan di atas, dukungan sosial Komida kepada para anggota umumnya dilakukan oleh staf Komida yang berada di lapangan, termasuk dukungan praktikal, moral, dan mentoring. Dukungan-dukungan ini menjadi penting, terutama karena perempuan sebagai anggota memiliki berbagai macam masalah yang membuat dirinya berkemungkinan besar merasa tidak berdaya. Masalah-masalah ini sesuai dengan apa yang diutarakan oleh Lord dan Hutchison (1993), yaitu masalah isolasi sosial pada kelompok perempuan berpendapatan rendah. Umumnya, mereka mengalami kondisi masa kecil atau masa dewasa yang sulit dan seringkali berbicara bahwa dirinya kekurangan dukungan dalam hidup mereka. Kemiskinan juga merupakan pengalaman yang membuat mereka lemah dan ini dialami oleh hampir seluruh perempuan dengan pendapatan rendah. Konsekuensinya adalah individu memiliki self-esteem yang rendah, opsi yang sedikit, dan keterbatasan pengalaman untuk mengambil keputusan.

Dukungan Komida sebagai praktik keuangan mikro, secara khusus juga diupayakan untuk mencapai kesetaraan gender dan pengentasan kemiskinan. Harapannya, perempuan dapat memiliki peluang dan kesempatan untuk berdaya, serta memperoleh level kehidupan yang lebih baik dari sebelumnya. Perempuan juga mampu menjadi elemen penting yang berperan dalam menopang perekonomian keluarga. Pada praktiknya, dukungan yang paling tampak dilakukan oleh Komida tertelak pada dukungan praktikal dan moral. 
Dukungan praktikal lebih difokuskan pada pelatihan dan memastikan kesanggupan anggota, termasuk tanggung jawab bersama apabila ada anggota lain mengalami kesulitan mengembalikan pinjaman. Dukungan berupa pelatihan tentang layanan yang diberikan menjadi krusial dalam membentuk pengetahuan dan pemahaman dari anggota. Wahid (2014) menambahkan bahwa pengetahuan dan keterampilan dasar dalam memahami sektor keuangan merupakan aspek utama dalam mewujudkan inklusi finansial. Tanpa pemahaman mengenai sektor keuangan yang memadai, kemungkinan masyarakat miskin malah bisa menjadi korban dari transaksi keuangan yang ada.

Dukungan praktikal lainnya yang diberikan secara nyata untuk memberdayakan perempuan pra-sejahtera adalah melalui program layanan utama, yaitu layanan pinjaman dan simpanan. Kehadiran layanan pinjaman mendorong anggota untuk mampu mengembangkan usaha (anggota A dan C) ataupun berani mulai mengembangkan usaha (anggota B). Bahkan, anggota B menggunakan pinjaman juga untuk merenovasi rumah dan anggota $C$ untuk membantu kebutuhan rumah tangga. Di sisi lain, kehadiran layanan simpanan membantu anggota untuk mau dan mampu menabung. Kegunaan utama layanan simpanan adalah supaya anggota dapat berjaga-jaga ketika sulit untuk membayar pinjaman dan memiliki dana cadangan untuk kepentingan masa depan keluarga.

Dengan adanya dukungan praktikal tersebut, anggota Komida mampu terlibat secara lebih aktif untuk memimpin, menyuarakan pendapatnya, serta berpartisipasi dalam kegiatan ekonomi. Keterlibatan dan partisipasi merupakan salah satu elemen penting dalam proses pemberdayaan. Menurut Lord dan Hutchison (1993), individu akan memperoleh kepercayaan diri yang lebih baik apabila dapat berpartisipasi dan terlibat dalam aktivitas komunitas. Keterlibatan dalam aktivitas, kelompok sosial, atau tindakan sosial akan meningkatkan interaksi sosial dan menurunkan isolasi sosial.

Dukungan moral lebih difokuskan kepada upaya membangun relasi yang positif, sehingga anggota memiliki loyalitas terhadap Komida. Selain itu, dukungan moral juga diberikan kepada anggota bermasalah dengan harapan anggota memiliki niat untuk mengembalikan pinjaman walaupun secara perlahan. Dukungan moral dalam upaya membangun loyalitas anggota menjadi krusial dalam menentukan keberlangsungan LKM. Dengan tumbuhnya loyalitas dari anggota, maka akan mendorong tumbuh dan berkembangnya LKM bersangkutan.

Sementara itu, dukungan mentoring yang dilakukan terkait dengan kegiatan pendataan dan peninjauan. Kegiatan pendataan diupayakan untuk menganalisis kemampuan bayar, sedangkan kegiatan peninjauan adalah bentuk pengawasan penggunaan pinjaman dan pemberian motivasi kepada anggota yang sedang kesulitan. Hanya saja, peneliti menilai bahwa dukungan mentoring 
tidak terlalu tampak diberikan oleh Komida kepada anggota. Fokus kegiatan pendataan dan peninjauan lebih difokuskan pada upaya meminimalis risiko terjadinya anggota bermasalah. Fokus staf adalah melakukan analisis kemampuan bayar anggota dan memastikan bahwa pinjaman digunakan sesuai fungsinya. Sementara itu, hasil usaha anggota pada akhirnya bergantung pada bagaimana anggota mampu menjalankan usahanya dengan baik. Komida belum memiliki layanan intervensi lebih lanjut dalam upaya pengembangan usaha anggota. Padahal, Ledgerwood (1999) menjelaskan bahwa salah satu layanan penting yang sebaiknya dilakukan oleh LKM adalah layanan pengembangan usaha, sebagai upaya mendorong terjadinya pemberdayaan dan mencapai lompatan dalam skala produksi dan pemasaran.

Pada akhirnya, tujuan dukungan sosial yang diberikan oleh Komida adalah untuk mempertahankan keberlangsungan dan keberlanjutan dari Komida sendiri melalui pertumbuhan dari sisi jumlah anggota ataupun tingkat pengembalian pinjaman yang baik. Selain itu, juga mendorong anggota untuk dapat membuka dan mengembangkan usaha, serta memiliki keinginan menabung. Dengan demikian, perempuan dapat berpartisipasi secara lebih aktif dalam upaya meningkatkan ekonomi keluarga, serta terlibat dalam berbagai kegiatan Komida dan tidak semata menjalankan tugas domestik saja.

Permasalahannya, loyalitas anggota terhadap Komida justru membuat anggota mengalami ketergantungan. Setelah anggota selesai mengangsur, anggota umumnya kembali melakukan pengajuan pinjaman berikutnya. Tidak heran apabila para partisipan bertahan lama di Komida. Kondisi ini menjadi dilematis karena Komida pun perlu mempertahankan anggota, sehingga dapat memperoleh kecukupan secara finansial dan berkembang. Untuk itu, peneliti menyarankan kajian terkait praktik keuangan mikro terhadap perempuan yang masih perlu dikaji lebih lanjut. Pertanyaan apakah perempuan penerima layanan keuangan mikro benar mampu untuk berdaya dan hidup lebih sejahtera masih perlu dieksplorasi.

\section{SIMPULAN DAN SARAN}

\section{Simpulan}

Komida cabang Cikalongkulon memberikan berbagai bentuk layanan kepada perempuan prasejahtera, mulai dari dukungan praktikal, mentoring, dan moral. Bentuk dukungan praktikal yang diberikan berupa pelatihan bagi anggota dan pemberian fasilitas pinjaman dan simpanan. Bentuk dukungan mentoring adalah dengan melakukan analisis kemampuan anggota untuk melakukan 
pinjaman dan memastikan pinjaman digunakan secara tepat. Kemudian, bentuk dukungan moral memiliki tujuan untuk memperkuat relasi dengan anggota dan sebagai strategi mengatasi anggota bermasalah.

\section{Saran Teoretis}

Penelitian ini diharapkan mampu memberikan sumbangsih terhadap ilmu psikologi, terutama jika dikaitkan dengan relevansinya terhadap upaya pengentasan kemiskinan. Teori dukungan sosial pun pada kenyataannya tidak hanya dapat diterapkan pada pembahasan terkait dengan kesehatan, seperti yang telah banyak digunakan selama ini. Teori dukungan sosial memiliki kaitan yang erat dengan upaya pemberdayaan, terutama pemberdayaan kepada masyarakatmasyarakat yang kurang beruntung.

Bagi peneliti lain yang tertarik untuk melakukan tinjauan serupa, peneliti menyarankan beberapa hal. Penelitian ini memiliki kelemahan karena partisipan dipilih oleh staf Komida cabang Cikalongkulon. Umumnya, partisipan yang dipilih adalah mereka yang memang aktif, memiliki prestasi yang baik, dan telah lama bergabung di Komida. Selain itu, partisipan yang dipilih juga harus mampu berbahasa Indonesia untuk memudahkan proses wawancara. Hal ini menyebabkan anggota yang dipilih secara tidak langsung adalah mereka yang memiliki pendidikan yang cukup memadai dan masih cukup muda, sehingga mampu berkomunikasi bahasa Indonesia dengan cukup lancar. Padahal, terdapat beberapa anggota lain yang tidak mampu berbahasa Indonesia dan hanya dapat menggunakan bahasa Sunda.

Penelitian ini juga belum mampu menelusuri dan mengeksplorasi kondisi dan alasan mengapa sebagian anggota lain menjadi anggota bermasalah, baik dari sisi kehadiran maupun pengembalian pinjaman. Penelitian selanjutnya disarankan untuk dapat menggali informasi dari sudut pandang anggota-anggota yang bermasalah. Walaupun jumlahnya tidak banyak, namun kondisi ini tetap perlu menjadi perhatian dan penanganan yang tepat. Terakhir, peneliti juga menyarankan untuk melakukan kajian yang berfokus melihat dampak layanan keuangan mikro terhadap pemberdayaan perempuan. Sejauh ini, Komida memang dapat dikatakan sebagai salah satu praktik keuangan mikro terbaik di Indonesia, dilihat dari sisi jumlah anggota dan pengembalian pinjaman. Hanya saja, penelitian selanjutnya perlu mengkaji bagaimana dampak riil dari layanan terhadap pemberdayaan perempuan secara lebih mendalam. 


\section{Saran Praktis}

Hasil penelitian dapat dijadikan rekomendasi terkait praktik yang sebaiknya dijalankan oleh LKM, termasuk bagi cabang Komida yang lain dan bagi LKM lain di Indonesia. Peneliti menyimpulkan bahwa dukungan praktikal berupa ketersediaan layanan simpanan dan pinjaman mendorong anggota untuk mampu memulai ataupun mengembangkan usaha. Syarat untuk menjadi anggota pun relatif mudah, sehingga semakin banyak anggota yang memiliki keinginan untuk bergabung. Dengan adanya layanan simpanan, anggota pun terdorong untuk mulai menabung. Hasil tabungan anggota dapat digunakan untuk berjaga-jaga apabila suatu saat anggota kesulitan mengembalikan pinjaman.

Kegiatan pelatihan yang disediakan oleh Komida juga membuat anggota lebih memahami prosedur dan persyaratan layanan, sehingga anggota tidak dimanfaatkan oleh LKM. Dalam pemberian pelatihan dan melakukan kegiatan, anggota juga harus membentuk kelompok. Praktik ini dilakukan karena peminjam tidak memiliki kapital fisik yang memadai, sehingga pinjaman berkelompok merupakan bentuk jaminan sosial. Pembentukan kelompok berguna untuk meminimalisasi kemungkinan gagal bayar melalui kewajiban tanggung renteng.

Adanya dukungan moral yang diberikan kepada anggota mendorong mereka untuk menjadi loyal dengan Komida. Kunjungan yang dilakukan kepada anggota bermasalah pun membuat anggota tetap menaruh rasa hormat kepada Komida, serta berupaya untuk mengembalikan pinjaman secara perlahan. Hal ini tentu menjadi penting karena keberhasilan LKM yang berfokus pada profit adalah mampu memperluas jangkauan dan mempertahankan loyalitas anggota. Terakhir, dukungan mentoring lebih diupayakan untuk meminimalisasi risiko yang mungkin terjadi di masa depan. Dengan adanya pengawasan dan evaluasi, staf dapat memperkirakan dan menganalisis sejauh apa anggota memiliki kredibilitas untuk memperoleh pinjaman.

Sayangnya, Komida belum banyak menerapkan layanan pengembangan usaha dalam praktiknya di lapangan, sehingga keberhasilan usaha anggota tergantung dari kemampuan dan kapabilitas anggota sendiri. Peneliti menyarankan adanya layanan pengembangan usaha bagi anggota supaya mereka memiliki kapital manusia yang lebih memadai dan mampu mengembangkan usahanya secara lebih optimal. 


\section{REFERENSI}

Alba, B. (2018). To achieve gender equality, we must first tackle our unconscious biases. Ditemu kembali dari theconversation.com/to-achieve-gender-equality-we-must-first-tackle-ourunconscious-biases-92848

Albrecht, T. L., \& Adelman, M. B. (1987). Communicating social support. New York, NY: Sage.

Bandura, A. (1994). Self-efficacy. Dalam V. S. Ramachaudran (Eds.), Encylopedia of humanbBehavior (hlm. 71-81). New York: Academic Press.

Banerjee, S. B., \& Jackson, L. (2017). Microfinance and the business of poverty reduction: Critical perspectives from rural Bangladesh. Human Relations, 70(1), 63-91. doi: $10.1177 / 0018726716640865$

Brau, J., \& Woller, G. M. (2004). Microfinance: A comprehensive review of the existing literature.

The Journal of Entrepreneurial Finance and Business Ventures, 9(1), 1-28.

Business Insider. (2012). Hundreds of suicides in India linked to microfinance organizations. Ditemu kembali dari businessinsider.com/hundreds-of-suicides-in-india-linked-tomicrofinance-organizations-2012-2/?IR=T

Creswell, J. W. (2013). Qualitative inquiry \& research design: Choosing among the five approaches. Thousand Oaks, CA: Sage.

House, J. S. (1981). Work stress and social support. Reading, Mass: Addison-Wesley.

Ife, J. (2013). Community development in an uncertain world: Vision, analysis, and practice. Port Melbourne, VIC: Cambridge University Press.

Komida. (2018). Koperasi mitra dhuafa - We care the poorest women. Komida. Ditemu kembali dari http://mitradhuafa.com

KSP Mitra Dhuafa. (2018) Annual report: Laporan tahunan. Indonesia: Pengarang.

Ledgerwood, J. (1999). Microfinance handbook: An institutional and financial perspective. Washington, DC: World Bank.

Lord, J., \& Hutchison, P. (1993). The process of empowerment: Implications for theory and practice. Canadian Journal of Community Mental Health, 12(1), 5-22. doi: 10.7870/cjcmh1993-0001

Mahadi, T., \& Kartika, H. (2018). Awal tahun, jumlah keuangan mikro bertambah enam entitas. Kontan. Ditemu kembali dari keuangan.kontan.co.id/news/awal-tahun-jumlah-lembagakeuangan-mikro-bertambah-enam-entitas 
Malecki, C., \& Demaray, M. K. (2002). The relationship between perceived social support and maladjustment for students at risk. Psychology in the Schools, 39(3), 305-316. doi: 10.1002/pits. 10018

Mekar. (2017). Mendanai usaha perempuan: Mengenal lebih dekat lending partner Mekar, Komida. Mekar. Ditemu kembali dari blog.mekar.id/mendanai-usaha-perempuan/

Milgram, B. L. (2001). Operationalizing microfinance: Women and craftwork in Ifugao, Upland Philippines. Human $\quad$ Organization, 212-224. doi: 10.17730/humo.60.3.4jegdmbrv52tcwvd

Morduch, J. (2000). The microfinance schism. World Development, 28(4), 617-629. doi: 10.1016/S0305-750X(99)00151-5

Neuman, W. L. (2013). Metodologi penelitian sosial: Pendekatan kualitatif dan kuantitatif (7th ed.). Jakarta: Indeks.

Nurwati, N., \& Mulyana, N. (2017). Profil penduduk Kabupaten Cianjur. SHARE Social Work Journal, 7(2), 46-52.

Pomeranz, D. (2014). The promise of microfinance and women's empowerment: What does the evidence say? Ditemu kembali dari https://www.ey.com/Publication/vwLUAssets/EY__Microfinance_and_womens_empowerment/\$FILE/EY-The\%20promise-of-microfinanceand-womens-empowerment.pdf

Swain, R. B., \& Wallentin, F. Y. (2009). Does microfinance empower women? Evidence from selfhelp groups in India. International Review of Applied Economics, 23(5), 541-566. doi: 10.1080/02692170903007540

Syahrizal, I., \& Machdum, S. V. (2016). Upaya perusahaan non-bank dalam mengembangkan usaha kredit mikro, kecil, dan menengah (studi deskriptif pemberian dan pengembalian predit oleh PT “X”). Jurnal Ilmu Kesejahteraan Sosial, 17(2), 86-105. doi: 10.7454/jurnalkessos.v17i2.109

Teye, B., Coleman, M., \& Oykere, D. O. (2016). Empowering women through microfinance in some selected microfinance institution and small scale business women in Takoradi business area. Research Journal of Finance and Accounting, 7(14), 34-42.

United Nations Development Programme. (2019). Gender equality. Ditemu kembali dari undp.org/content/undp/en/home/gender-equality.html

Wahid, N. (2014). Keuangan inklusif membongkar hegemoni keuangan. Jakarta: Gramedia. 
Warby, B. (2014). Microfinance and poverty reduction: How risks associated with government policies affect whether microfinance alleviates poverty in Latin America (Disertasi tidak dipublikasikan). University of South Carolina, Columbia.

Whittaker, J. K., \& Garbarino, J. (1983). Social support networks: Informal helping in the human services. Hawthrone, NY: Aldine.

Yunus, M. (2007). Bank kaum miskin. Tangerang: Marjin Kiri. 